\title{
THE UNITED KINGDOM FORESTRY PLANS FOR THE DEDICATION OF WOODLANDS
}

\author{
By Harris E. VIDETO ${ }^{1}$
}

University of New Brunswick, Fredericton, New Brunswick

$\mathrm{T}$

HE UNITED KINGDOM is laying plans to produce one-third of her timber requirement as a normal feature of the economy. The excessive depletion of woodlands during two wars and in general the lack of consistent practice of what was considered best forestry, have of course ag. gravated an already unstable situation.

Of a land of some 56.2 million acres, the Acland Committee Report of 1918 reported some 3 million acres of forest land. It was yielding some 45 million c.f. ( 8 per cent of total consumption) or about $1 / 3$ of what it should have been doing under correct silvicultural management. During 1948 the U.K. is providing 27 per cent of its own timber-but the total volume is much below normal during this crisis period. Nevertheless the volume represented is far above what should be harvested. They now declare that neglect means waste and that forestry had been plagued with haphazard methods which cannot pay in any business. Three essentials of failure which were presented are: Unduly high working expenses, unsatisfactory technical methods and slack marketing machinery.

The concrete proposal is to dedicate land to the production of timber, regardless of ownership or change of ownership. Then the consistent application of systematic methods of forestry will be applied uniformly where they are needed.

It might be of interest at this point to compare the U.K.'s percentage of land area in forest to total land area with percentages for several European countries.

U.K. 1918 and $1948 \ldots \ldots \ldots \ldots \ldots$. $5.5 \%$ (97\% Privately owned)

At end 50 yrs. under Plan ......... $9.0 \%$

Sweden $\ldots \ldots \ldots \ldots \ldots \ldots \ldots . . .56 \%$

Germany $\ldots \ldots \ldots \ldots \ldots \ldots . \ldots 27.0 \%$

France $\ldots \ldots \ldots \ldots \ldots \ldots \ldots .19 .1 \%$

Belgium $\ldots \ldots \ldots \ldots \ldots \ldots \ldots, 18.4 \%$

Holland ............... $7.8 \%$

Denmark .............. $7.5 \%$

FOREST DEPLETION 1914/18 AND JUST AFTER

Some 450,000 acres were felled or devastated during the period. Small areas were planted by the owners, small areas were acquired by the Forest Commission and replanted, but most of the area was left to its own delinquent devices. From then to the last war, the felling policy was rather of the "couldnt care less" type. Between 1919/1939 only some 125,000 acres of private land were planted or replanted voluntarily. There were State grants of $£ 2 / a c$ for Softwood and $£ 4 / a c$ for Hardwood. In the same 25 years little in the way of new area entered forest land classification. The Forestry Commission has acquired 700,000 acres of which some 435,000 acres

1. Harris E. Videto is presently studying Forest Economics at the University of London, England. He is on leave from the University of New Brunswick on a Beaverbrook Overgeas Scholarship. 
have been planted. Let us examine the authority and organization which will be responsible for the "new look" in British forestry.

\section{The Forestry COMmission}

The Commission has had 28 years of experience, having come into being in 1920 under authority of the Forestry Acts, 1919.

The Chairman and nine members are appointed by His Majesty by warrant. They hold and vacate office in accordance with the terms of the instrument of appointment.

The Acts provide that at least three Commissioners must have special knowledge and experience of forestry and that at least one Commissioner shall be a technical forester. The present Chairman, Lord Robinson, is an Oxford forester and considered a very able forester and administrator. The practice has grown up (and is favored by the Commission) that the three political parties shall be represented on the Commission. Party controversy on Forestry matters is avoided by this means. No Commissioner can now be a member of the House of Commons. The various parts of the country are represented by either technical men or men of public standing and influence-and all are interested in forestry.

Today the Commissioners are paid such sums as the Minister and Treas. ury agree upon. The Commissioners in turn, determine, appoint, employ and dismiss such officers and servants as they deem necessary to carry out the work of the Forestry Acts 1919 to 1947. These latter are paid such salaries as Minister determines and Treasury agrees to.

To carry out the Post-War Policy which will entail operations on a much larger scale and closer relations between Commission and owners of private woodlands, certain decentralization changes are suggested.

The present organisation chart is:

\section{Forest Commission}

$\begin{array}{cc}\text { H.Q. } & \text { U.K. (13 Divisions) } \\ \text { Secretariat } & \text { England \&3 Wales Scotland } \\ \text { (Research } & \text { (each having) } \\ \text { Finance } & \text { Assistant Commissioner. } \\ \text { Technical_- (Publications } & \text { Divisional Officers. } \\ \text { (Special Enquiries } & \text { (each with) } \\ & \text { Groups of Forests. } \\ & \text { Each Group under } \\ & \text { Forester. }\end{array}$

It is interesting to know that the working funds (budget) of the Commission have always been approved ahead by the Government, usually for five year periods. 
Under the Dedication Plan the Forestry Commissioners become the Forest authority for its execution.

\section{EARly Support for the New Plan}

In January, 1942, the Royal Scottish Forestry Society in a succinct report on Estate Forestry declared in part as follows: "The Society strongly urges the formulation now of a new policy for private woodlands..." "The new policy must ensure that timber production will be an economic proposition..." "If adequate provision is made on these lines owners should be made to conform ..." ". . the Society therefore proposes ... 1. Ap. pointment of a competent Forest Authority charged with the direction of national and private estate forestry." "2. Registration with Forest Authority of privately owned woodlands.... the owners to manage and maintain their woodlands according to the principles of good silviculture . .."

About the same time, the Royal English Forestry Society was saying, in part, in their memorandum, " . . . while believing it to be in the national interest that State and privately owned woodlands should continue to coexist, approve the principle that the latter should be brought under a measure of control and supervision by a reconstituted Forest Authority, independent of party politics, on which private owners shall be represented."

The main objectives would be:

"1. To ensure continuity of good management.

2. To prevent devastation by timber speculators.

3. To secure for both state and privately owned woodlands a reasonable annual return ..."

"The plan should be so designed that while it prevents abuses in badly managed woodlands, it allows freedom of enterprise in those which are well managed." Owners of the well managed woodlands "should be allowed to register their estates as 'Approved Estates"". Such owners would "submit for approval a satisfactory scheme of silvicultural management" and "provide evidence that the woods are under competent management". They looked to the day when with experience of the scheme and a sufficiency of trained foresters, such registration should be made compulsory.

In May, 1942, the Central Land Owners' Association in a report on Private Woodlands, offered constructive suggestions including among the fundamental needs "a reconstituted central authority on which the supervision of private woodlands is dealt with separately to State owned forests".

In June, 1943, H. M. Forestry Commissioners presented their report on "Post War Forest Policy" to the Chancellor of the Exchequer. In this the whole situation was reviewed and the Dedication plan sketched in. The same month the Commissioners convened a conference to discuss the treatment of Private woodlands. To this conference representatives of the follow. ing organizations were invited and attended:

The Central Land Owners' Association

The Scottish Land and Property Federation

The Land Union

The Royal Scottish Forestry Society

The Royal English Forestry Society 
This conference agreed on the "Seven fundamental principles". It also agreed upon the dedication procedure, that financial accounts are essential to good management, that the owner must be prepared to bear a substantial proportion of the cost of the scheme, that should the State ever have to assume control of any woodland, previous assistance should be taken into account and that the assistance should cease when the woodlands became self-supporting.

The conference did not favor possibility of "rushing" owners into the Dedication system, or of delaying tactics by the owners against the Authority. The Commission felt the procedure as laid down was sound and that good will on both sides would assure its success. The small amount of concrete aid by the State in the past was mentioned. Only 3 per cent to 4 per cent of standing utilisable timber in 1939 could be credited to State planting. Planting is very vital in the U.K. There was some difference of opinion on grant proposals. The Dedication Scheme when published set out two bases of grants.

We must now examine the Dedication of Woodlands Scheme which was published January 1948.

The Dedication of Woodiands

The Seven fundamental principles approved by the various Associations, the Commission and the Government are:

1. The rehabilitation of the woodlands must proceed with both certainty and rapidity.

2. All planting and natural regeneration acceptable instead of replanting, must be properly looked after up to the stage of satisfactory "estab. lishment".

3. In every case the owner must reach an early decision as to whether he is prepared to proceed with the work of rehabilitation.

4. If an owner is so prepared and can give satisfactory assurances he is deserving of financial assistance from the State.

5. Where no satisfactory assurances are forthcoming within a stated period, the State should acquire the land.

6. The war time system of felling licences must continue until the reserve of standing timber can be adjudged satisfactory.

7. Some degree of control of the silviculture of private woodlands is necessary.

To give effect to these principles it is proposed to dedicate land to timber production regardless of ownership. Some three million acres are woodland today. It is estimated that a further two million acres could be reclaimed and more wisely turned to tree production in the next 50 years. This dedication will make possible the long term concentration of systematic methods of forestry.

Since many owners have been doing a creditable forestry job for years, it is proposed to initiate the plan on the more derelict lands. Hence the Forestry Commission has to discover which lands should be dedicated first. Eventually, all lands would be so treated. 
When lands are selected by the Commission, the owner would be so informed and, subject to special grounds of appeal, be given the option of dedicating or transfer to Forest Authority. If he agrees to dedicate his woodlands he agrees to:

1. Use the land for timber as a maincrop.

2. Follow a Forest Authority approved operations plan.

3. Employ skilled supervision (it may be himself).

4. Keep adequate accounts.

In return the State stands ready to assist in technical, advisory and financial ways.

On the other hand he may choose to allow the State to acquire the land. The financial side to the owner is twofold-grants and loans.

Basis I: To repay the owner 25 per cent of the approved net annual expenBasis II: diture on the dedicated woodlands and availability of loans.

1. A planting grant of $£ 10$. per acre, planted or replanted after dedication-HW or SW.

2. Loans in addition.

3. A maintenance grant for 15 years of 3s. $4 \mathrm{~d}$. per acre per year an planted or maintained dedicated lands.

4. A maintenance grant of 15 years of $3 \mathrm{~s} .4 \mathrm{~d}$. per acre per year from date of dedication of all productive forest woodlands other than new Loans. plantings.

Loans to cover a substantial part of replanting may be approved at $3 \%$ interest. Repayment may start at the end of the first year, or after 15 years -in all cases repayment in 50 years.

Deeds of Covenant are provided for the formal pledges of State and owner.

\section{Plan of Operation}

The Commission has drawn up a basic "frame" of general rules covering planting, thinning and felling for ten year periods. This Plan will contain Form II: Details of Ownership and Map of Woodlands. Form II are Statements. Summary classification and description of Forest Lands. Form III Detailed Classification. Then follows the owners "Objects of Management". Form IV Prescriptions. This outlines the acreages of planting, thinning to be undertaken during first five years and outline for 6th-10th years inclusive. Special sub-forms are drawn up and an owner's generalized "methods of working" statement.

Finally there are the five purely forest "record" forms and the simple and standardized form of accounts.

Uniform costing and standardized account forms are live issues in Eng. land. Many industries and public utilities have long used their own standard forms. Also some 30 trade and professional associations have standard accounting systems which members can adopt voluntarily. Certainly from the point of view of taxation, agreement on terms and interpretation, costing comparison and general ease of application, there is much to be said for it. 
We in Canada also vary from no accounts at all to the most highly deceptive creations.

\section{What WILL IT Cost?} forestry.

In the decade before the war, the State spent $£ 13.8$ million (net) on

The present post-war plan has been outlined as:-

1. "Desirable" program which would include $1,100,000$ acres of planting in the first decade. It would cost an estimated net $\$ 41.2$ million.

2. The "Intermediate" program, including 875,000 acres of planting in the first decade. This program to cost $£ 32$ million net.

\section{COMMENT}

The aforegoing is an attempt to summarize the frame in which the Dedication of Private Woodlands was born, followed by an outline of the plan itself. I think it is well to realize that this plan did not originate with the Labour Government as part of their Nationalization picture. Rather it has been evolutionary. Ideas and sporadic attempts, trial and error of the past, much failure and few successes were soberly rated in the 1943 PostWar Forest Policy report.

A second fact is that the Technical Foresters through their societies and the Property Owners' Associations have contributed greatly to the anvil beating of the shape the plan now bears. No move was made by the Government of the day without free discussion between the Forestry Commissioners and interested and/or informed parties.

The problem has been squarely faced in its National aspect. Even broken down into units of private woodlands, the job is considered beyond the unaided powers of the owner.

Surely at long last the distinction is being made between "free enterprise" and "free exploitation" in forestry. Canada has still to make that distinction.

\section{REFERENCES}

1918 Final Rpt. Reconst. Comm. (Forestry Sub-Comm) H.M.S.O.

1919.1927 Forestry Acts 1919-1927. H.M.S.O.

1943 Post-War Forest Policy, H.M. Forestry Commissioners. Cmd. 6447. H.M.S.O.

1944 Post-War Forest Policy. Private Woodlands. Cmd. 6500. H.M.S.O. H.M. Forestry Commissioners.

1945 Forestry Act 1945. Chapter 35. 889 Geo. 6. H.M.S.O.

1947 Forestry Act 1947. Chapter 21, 10 \& 11. Geo. 6. H.M.S.O.

1948 The Dedication of Woodlands, Principles and Procedure. H.M. Forestry Commission Booklet 2. H.M.S.O.

1948 Economic Survey 1948 (White Paper). Cmd 7344. H.M.S.O. 